\title{
The Whole Process Cost Management for Construction Projects in Higher Vocational Colleges of China
}

\author{
Chunming Liu ${ }^{1, a}$, Qi Zhang ${ }^{2, b}$, Liang Liu ${ }^{1, \mathrm{c}}$ and Hongtao Peng ${ }^{3,4, \mathrm{~d}^{*}}$ \\ ${ }^{1}$ Beijing Vocational College of Agriculture, Beijing 102442, China \\ ${ }^{2}$ China State Construction International Co., Ltd, Beijing 100125, China \\ ${ }^{3}$ College of Water Resources and Civil Engineering, China Agricultural University, Beijing 100083, \\ China \\ ${ }^{4}$ Institute of Soil and Water Conservation of Chinese Academy of Sciences and Ministry of Water \\ Resource, Yangling, Shanxi 712100, China \\ apwb@cau.edu.cn, ${ }^{b} z q 851023 @ 126 . c o m,{ }^{c} 1400343721 @ q q . c o m,{ }^{d}$ pht10@sina.com \\ *Corresponding author: Tel.: +86 13671124965. E-mail addresses: pht10@sina.com
}

Keywords: Higher vocational college, Construction project, Whole process, Cost management, Auditing system.

\begin{abstract}
In recent years, owing to the rapid development of China's vocational education, the investment on construction projects in higher vocational colleges is huge, and some problems turn up that the original system does not fit for the cost management of construction projects in higher vocational colleges of China. Aiming at the current situation and problems of cost management for construction project in higher vocational college, this research analyzed the responsibilities of infrastructure department, contractor, supervisor and audit department in cost management of the higher vocational college, and clarified that the whole process cost management is an important mean to achieve investment goals in the higher vocational college, also expounded the necessity of establishing the internal cost auditing system of capital construction in higher vocational college. Adopting the method of tracking audit can be effective to supervise the whole process cost management, to promote the infrastructure department in higher vocational college to strengthen management, and to improve the capital efficiency.
\end{abstract}

\section{Introduction}

In recent years the enrollment size and the number of students in higher vocational colleges has continued to increase. In 2009, in the 2263 regular higher education schools in China, there are 1079 undergraduate colleges and 1184 higher vocational (junior) colleges [1]. The statistic of development in higher vocational colleges in Beijing area between 2001 and 2010 was shown in Table 1[2, 3].

Table 1 Statistics of developments in higher vocational colleges in Beijing

\begin{tabular}{|c|c|c|c|c|}
\hline Statistical year & Number of students & Enrollment & Number of graduates & Number of schools \\
\hline 2001 & 65000 & 29000 & 12000 & 8 \\
\hline 2005 & 127000 & 47000 & 32000 & 20 \\
\hline 2010 & 126500 & 43800 & 46800 & 25 \\
\hline
\end{tabular}

With the enrollment increasing, it gradually brings enormous pressure to the basic school conditions and teaching facilities of higher vocational college. Because of the occupation education development and "hardware" requirement of demonstration teaching evaluation, all higher vocational colleges have carried on a large amount of basic construction, behind this needing huge fund support. As the“Educational Statistics Yearbook of China"shows: in 2005 the higher vocational education fund investment in China was about CNY 11,000,000,000; and by 2009 this figure has reached about CNY 40,000,000,000. In 2010,“Twelfth Five-Year Plan”pointed out that the country would continue to strengthen the occupation education. At present, it exists huge space in controlling the construction project cost of higher vocational college. Large-scale construction exists in many higher vocational colleges, but a number of projects eager to start early for the lack of scientific proof, decision, which led to the disorder of construction, capital waste problem. If the project investment is controlled 
effectively, through cost control to regulate higher vocational college construction project, it can save a lot of money.

\section{Characteristics of higher vocational college construction project and existing problems of project cost management}

Huge capital demand, lack of necessary cost management mechanism: including the teaching building, office building, library, gymnasium, dormitories, canteens, and many training establishments with higher vocational education characteristics, mostly serving as the teaching need without profit purpose, it lacks the necessary cost management mechanism in a relatively closed environment of the higher vocational college, and being out of line with the social market economy.

Construction period will be influenced by teaching: generally small-scale projects have to be finished in one school year (or term), taking measures to accelerate building become a regular event during the construction stage, and causing the project cost increase.

The lack of scientific management methods and high level manager at the post of cost control: higher vocational college construction project management mode was that the leadership of infrastructure department took the lead, and the construction administration personnels were responsible for the management, which leaded to the administrative intervention, layman guiding adept phenomenon, not playing a real cost management role.

Maintenance cost was large: quality problems, effected by the relatively low professional level of the college project management, may be repeated repaird not completely solving the problem. These problems affected the normal use and made maintenance cost increase.

\section{The whole process of project cost management in higher vocational college construction project}

The development of higher vocational college is still in the exploratory stage, there existing problems in the project management. The infrastructure project cost management in higher vocational college should be carried out from the project investment decision-making phase, design phase of the project, the project construction bidding stage, construction stage, the project completion settlement audit stage with the whole process cost management method. Problems and implementing control countermeasures of the project cost management in higher vocational colleges were shown in Table 2. The cost determination at various stages of the project in higher vocational college construction projects is shown in Fig. 1 [4].

\section{The implementation of whole process tracking audit of construction project cost in higher vocational college}

Content of the project cost whole process tracking audit. Taking the audit professional work into account, at present the "internal audit outsourcing" approach is adopted, it is that commissioned to the social project cost advisory orgnaization with the corresponding qualification, the specific content of audit supervision is carried out on vocational colleges to implement the entire process of project cost from the feasibility study stage until project completion node (summary) calculate stage throughout the whole process of constrution project.The main content was shown in Fig. 2.

key points of the whole cost tracking audit process in higher Vocational College engineering. Make audit principle clear: including basis of relevant laws and regulations which the state and local enacted, such as construction law, contract law, bid invitation and bidding, project price settlement procedures; various types of construction contracts, equipment, materials supply agreement, engineering design, modification negotiation documents, meeting minutes, effective business visa, project site survey record and other special basis. 
Table 2 Problems and implementing control countermeasures of the project cost management in Higher Vocational Colleges

\begin{tabular}{|c|c|c|}
\hline $\begin{array}{l}\text { Implementation } \\
\text { phase }\end{array}$ & The existing main problems & $\begin{array}{c}\text { Control measures of whole process cost } \\
\text { management }\end{array}$ \\
\hline $\begin{array}{l}\text { The investment } \\
\text { decision } \\
\text { making stage }\end{array}$ & $\begin{array}{l}\text { (1) Project proposals prepared simply } \\
\text { (2) The feasibility study report of project } \\
\text { being not in-depth }\end{array}$ & $\begin{array}{l}\text { (1) Scientific decision-making, detailed argument } \\
\text { (2) The accurate estimation of investment }\end{array}$ \\
\hline Design stage & $\begin{array}{l}\text { (1) Not fully impling the design bidding } \\
\text { (2) The lack of design scheme optimization } \\
\text { (3) Not carrying out design stage } \\
\text { management system }\end{array}$ & $\begin{array}{l}\text { (1) Carrying out design bidding } \\
\text { (2) To optimiz the design } \\
\text { (3) Quota design not exceeding the total } \\
\text { investment }\end{array}$ \\
\hline $\begin{array}{l}\text { Construction } \\
\text { bidding stage }\end{array}$ & $\begin{array}{l}\text { (1) Bidding document being not scientific } \\
\text { (2) Rent-seeking behavior } \\
\text { (3)Valuation with bill quantity of } \\
\text { construction works being not accurate } \\
\text { (4) Bidding evaluation being not sufficient }\end{array}$ & $\begin{array}{l}\text { (1)Using the valuation with bill quantity of } \\
\text { construction works, making control price } \\
\text { (2) Carrying out inviting public bidding proxy } \\
\text { mode } \\
\text { (3) Qualification prejudication, effective } \\
\text { scientific evaluation of the lowest bidding price } \\
\text { method } \\
\text { (4) Using the standard text of contract }\end{array}$ \\
\hline $\begin{array}{l}\text { Construction } \\
\text { stage }\end{array}$ & $\begin{array}{l}\text { (1) The design depth being not enough, } \\
\text { modified frequently. } \\
\text { (2) Supervision system being not perfect } \\
\text { (3) Failing to pay for the project timly } \\
\text { (4) Being against the construction } \\
\text { procedure }\end{array}$ & $\begin{array}{l}\text { (1) Auditing construction organization design } \\
\text { (2) Seting up quality control points } \\
\text { (3) Strict control of engineering modification } \\
\text { (4)Supervising construction progress } \\
\text { (5) Controling contractor's claims }\end{array}$ \\
\hline $\begin{array}{l}\text { Audit of } \\
\text { completion } \\
\text { settlement } \\
\text { stage }\end{array}$ & $\begin{array}{l}\text { (1) Compiling completion settlement } \\
\text { agreement not in accordance with the } \\
\text { contract or bidding documents } \\
\text { (2) Not carrying out auditing } \\
\text { (3) The audit system improvement in } \\
\text { higher vocational college remaining being } \\
\text { perfected }\end{array}$ & $\begin{array}{l}\text { (1) Verifying whether completion settlement is } \\
\text { agree with the contract } \\
\text { (2) Carefully accounting engineering quantity and } \\
\text { charge standard } \\
\text { (3)Strictly investigating design modification } \\
\text { (4)Strictly carrying out the system of first instance } \\
\text { supervision, infrastructure audit review, and final } \\
\text { audit }\end{array}$ \\
\hline
\end{tabular}

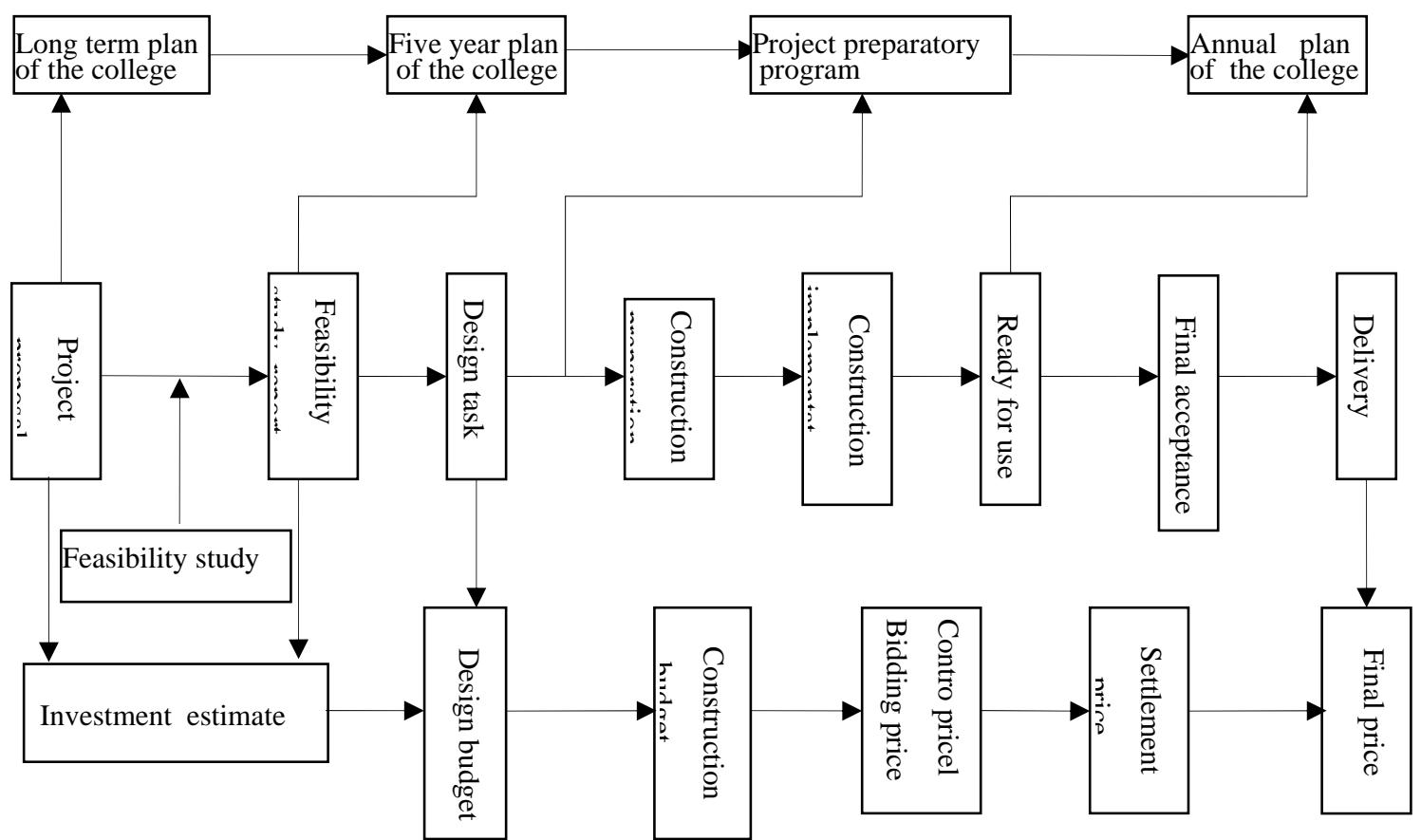

Fig. 1 The schematic diagram of cost determination at various stages of construction project procedures in the higher vocational college 


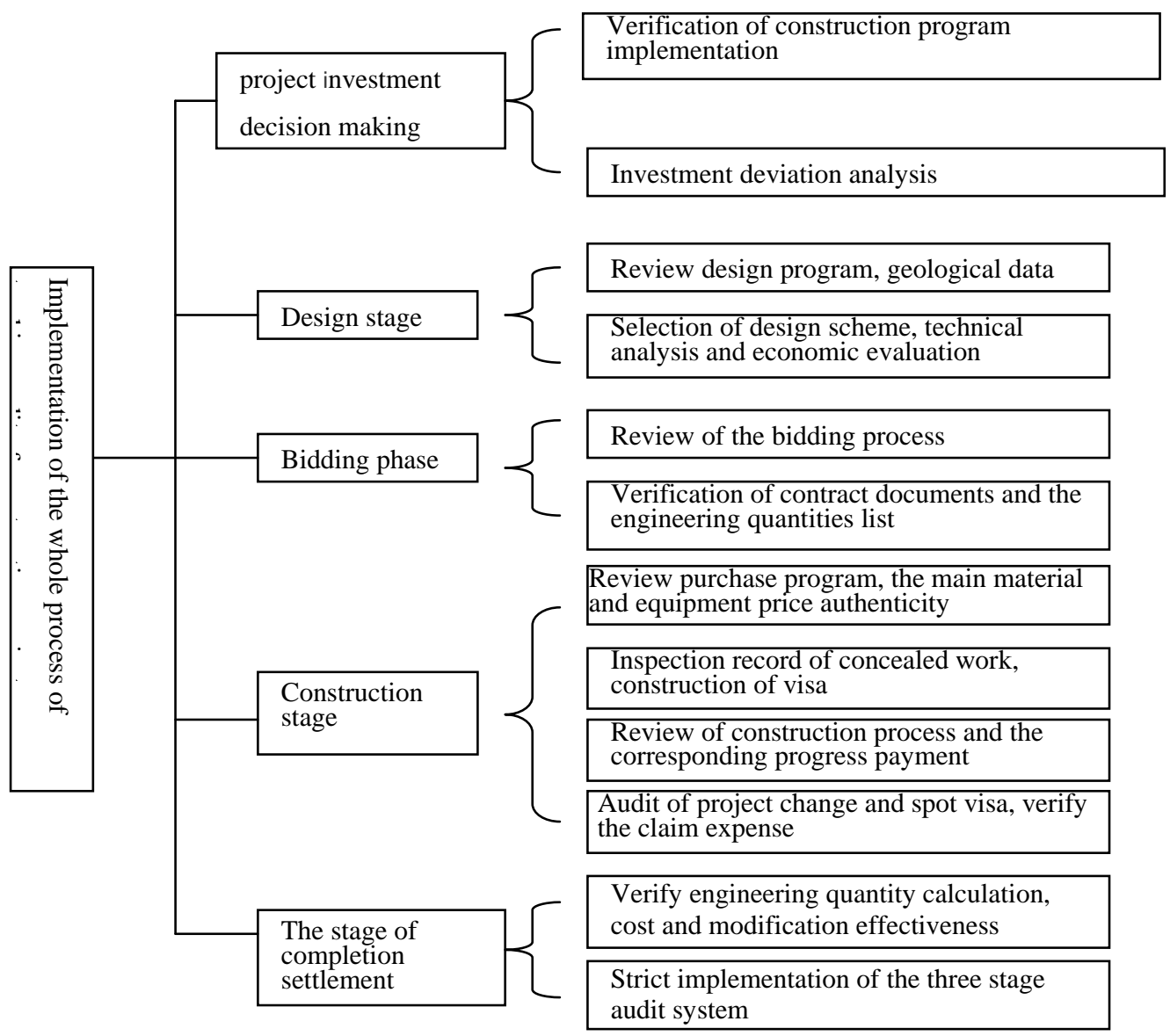

Fig.2 The whole process of tracking audit

Focus on the early stage of the audit in the construction projects: the early stage decision of construction project and design stage plays a decisive role in the control of construction project cost, the influence that the early stage decision on cost of some project reachs to more than $75 \%$ [5].Therefore, this stage is the key point of the audit. Specificly including: whether the analysis decision being scientific, conscientiously doing a good job on the feasibility study of examination and evaluation; whether the preparatory work procedure being reasonable and legal, improving reliability of project demonstration; audit design bidding; reviewing the artificial person certificate, business license, qualification grade of the tender company. Coordinating all relevant parties work: how to do labor division coordination of many companys and departments, as well as making clear respective responsibility and authority, is very important in ensuring the completion of the project on schedule and the smooth implementation of tracking audit in the construction of higher vocational colleges.

Cost influence of construction project at various stages of the project construction in higher vocational college was shown as in Fig. $3[6,7]$. Responsibilities of various departments in the course of engineering cost management in higher vocational colleges were clear in Table 3.

Problems that the current higher vocational college will face when tracking audit practice. The audit environment needs to be further improved. From the macro view, tracking audit of construction project is still in the exploration stage in current higher vocational colleges, the state having not yet issued specific laws and regulations to standardize its operation process, but having not formed a complete and scientific theory; from microcosmic view, construction project auditing still belongs to the scope of internal audit in higher vocational college, and it does not have national audit authority and the mandatory. The audit risk control needs to be strengthened. In the implementation of tracking the whole construction project audit process in higher Vocational College, because the audit object, audit contents and audit scope are enlarged relative to the traditional audit model, causing the relevant audit department easily being involveed in project management because of its unclear location, even with the infrastructure or other departments having jurisdiction conflict. Because of a variety of interests staff of some functions will think that the audit department deprive 
some of its power, resulting in the non-intention to cooperate with audit, and improving the audit risk.Therefore, in the face of these risk control consciousness also needs to be further improved.

Project impact

degree (\%)

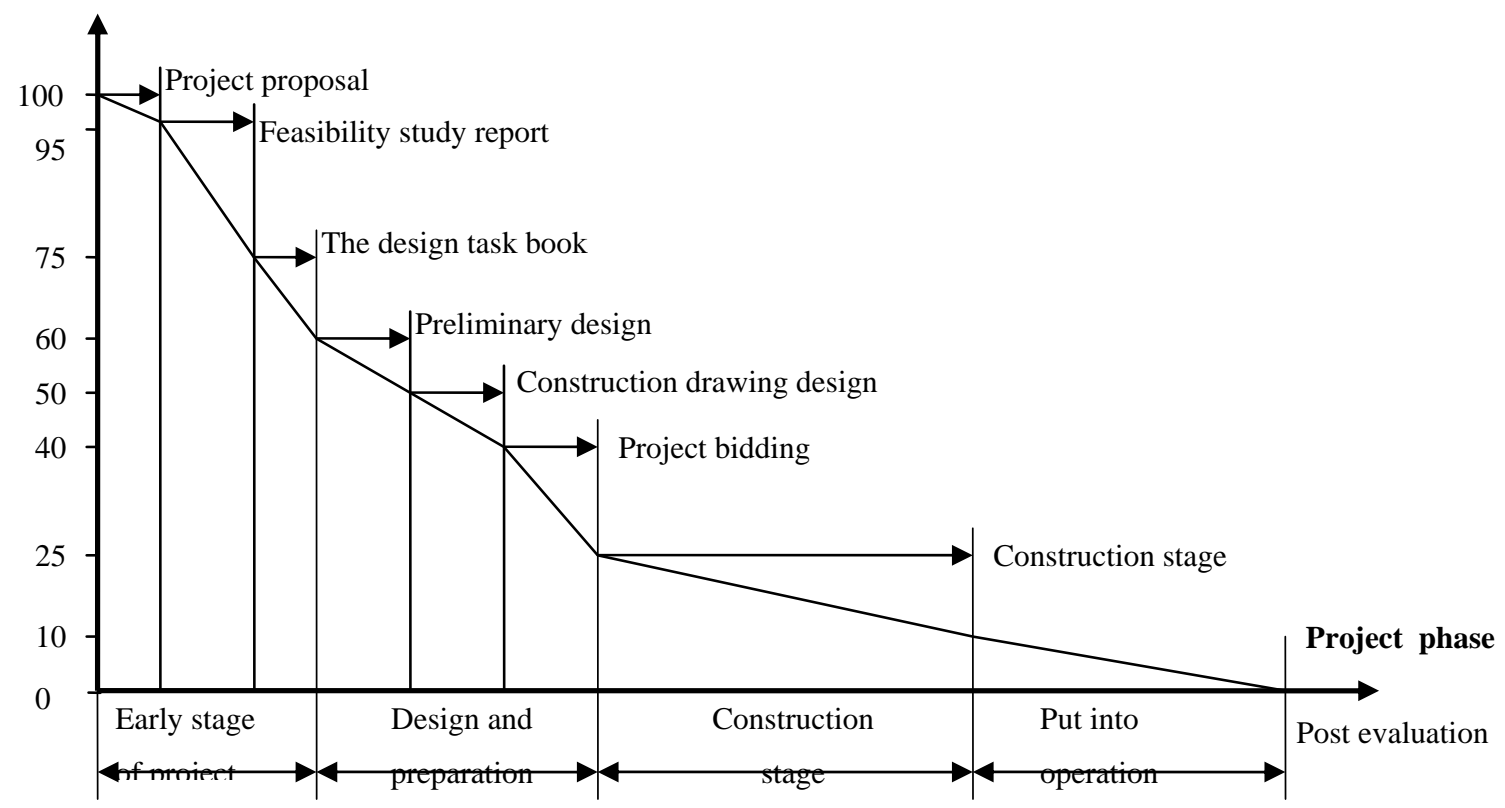

Fig.3 Cost influence curve of construction project at various stages of the project construction in higher vocational college

Table 3 Responsibilities of each department in the course of engineering cost management in higher vocational colleges

\begin{tabular}{|c|l|}
\hline $\begin{array}{c}\text { Department } \\
\text { name }\end{array}$ & \multicolumn{1}{c|}{ Department responsibilities } \\
\hline $\begin{array}{c}\text { Infrastructure } \\
\text { department }\end{array}$ & $\begin{array}{l}\text { Being the project legal representative, being the most direct cost management in project } \\
\text { construction process in higher vocational colleges. }\end{array}$ \\
\hline Audit & $\begin{array}{l}\text { Infrastructure project cost audit supervision on higher vocational college, to standardize the } \\
\text { construction cost management, playing the important role of saving energy and increasing } \\
\text { efficiency. }\end{array}$ \\
\hline $\begin{array}{c}\text { Discipline } \\
\text { inspection }\end{array}$ & $\begin{array}{l}\text { Participation in important link of project cost management in higher vocational college, such as } \\
\text { construction project bidding, procurement, and etc. Being responsible for the supervision and } \\
\text { inspection on engineering cost management process for the implementation of national laws, } \\
\text { regulations, guidelines, policies and regulations, decisions of the college, to monitor the object } \\
\text { being law-abiding, clean-fingered, self-discipline supervision and education. }\end{array}$ \\
\hline $\begin{array}{c}\text { Financial } \\
\text { department }\end{array}$ & $\begin{array}{l}\text { Responsible for financial management and accounting work relevant to basic construction project } \\
\text { cost in higher vocational college.Reasonably budget planning, implementing control and } \\
\text { management on budget, specificating economic order in college, ensuring the country financial } \\
\text { policy and financial system being implemented. }\end{array}$ \\
\hline Logistics & $\begin{array}{l}\text { the project manager after the completion of basic construction in higher vocational colleges.In the } \\
\text { course of engineering construction to somehow involve in the project cost management process } \\
\text { according to the need }\end{array}$ \\
\hline
\end{tabular}

\section{Conclusions and Suggestions}

The examination and approval procedure must be implemented strictly. The government should continue to give policy support to higher vocational colleges. The construction project examination and approval system, examination and approval procedure should be controlled strictly in the higher vocational college, avoiding waste. At the same time, higher vocational college should strive to broaden the financing channels to solve the problem of shortage of construction funds. Project management mechanism should be strengthened. The current main problem in construction project whole process management mechanism in higher vocational colleges is not perfect, and cost control 
consciousness of some personnel may be not strong, even some leader. Responsibilities in charge of construction, supervision, design, construction, and other units of the whole process cost control should be clear. The system of engineering project audit is still not perfect; it needs further legislation for the real implementation of engineering project cost comprehensive audit.

\section{Acknowledgements}

This work was supported by " Special Fund of Department of Water Resources and Architectral Engineering, Beijing Vocational College of Agriculture (No. 2011058)”.

\section{References}

[1] Education Statistic of 2011 on http://www.stats.edu.cn

[2] Beijing“eleven five"period of higher occupation education development planning on http://www.bjedu.gov.cn

[3] F.Y., Zhang. Beijing Education (Higher Education Edition), 2011(3), p.7 (in Chinese)

[4] National cost engineer training materials. Determination and control of engineering cost (Second Edition). Beijing: China Planning Press, 2001, 25-28

[5] S.Y. Wu. Research on The whole process cost management of construction project [D]. Hefei: HeFei University of Technology, 2009 (in Chinese)

[6] H.T. Peng, Z.Y. Qiu, X.Y Yao, P. Cheng, M. Zhu. Construction Technology Vol. 40(2011), p.60 (in Chinese)

[7] H.T. Peng, X.Y Yao, P.J. Li, J. Wang: Education and Economy, 2011 (3), p.37 (in Chinese) 